Diabetic Gangrene Medical News, 1888, vol. liii., p. 705 . Auché et le Dantec, Nouvelle Mucorine Pyogène, Archives de Médecine Expérimentale, tome vi., p. 853. Baldy, vide discussion on Noble's paper; also unpullished cases by letter. Barker : On two Cases bearing upon the Question of the Limitations of Enterectomy, Transactions of the Getahren der Narkose fur den Diabetiker, Deutsche Medicinische Wochenschrift, 1894, Band xx, SS. 359, 380, 404. Berger (Breast case): Bulletin de la Société de Chirurgie, 1885, tome ix., p. 370. Beyea: Case of Multilocular Pseudomucinous Cystadenoma of the Right Orary associated with Pronounced Symptoms of Diabetes, American Journal der Eiterung neben Staphylococcus Aureus, Centralblatt fiir Bacteriologie, Band iv., S. 577. Bull : Report of a Case of Pancreatic Cyst treated Diabetes, New York Medical Journal, 1887, vol. xlvi., p. 376. Chauvel : Gangrène de Deux Pieds, Glycosurie chez un Paludique, Amputation, Gangrène de Deux Pieds, Glycosurie chez un Paludique, Amputation,
Guérison, Gazette des Hopitaux, 1883, p. 549. Churton: A Case of Guerison, Gazette des Hopitaux, 1883, p. 549. Churton: A Case of Pancreatic Cyst with Diabetes; Incision of the Cyst, Transactions of the Clinical Society of London, Vol.xxvii., p. 245. Claisse et Durrieux, Epit'Anatomie, November, 1899, p. 978. Cohen: Glycosuria in Connexion with Appendicitis, Diabetes Mellitus, New York Medical Journal, 1894, vol. 1x., pp. 161-165. Croom : Glycosuria Complicating an Ovarian Tumour and Ovariotomy. Brit. Med. Jour., 1895, vol. ii., p. 1362. Wochenschrift, 1894, Band xxxi., S. 1157. Davis: Diabetic Gangrene, Journal of the American Medical Association, Chicago, 1898, vol. xxxi., pp. 103-105. Di Pietro: Della Glicosuria Etimera nei Traumatismi, Rivista Chirurgica e Terapeutica, Napoli, 1888, vol. X., pp. 408, 417. vol. ii., p. 358. Matthews Duncan: On Puerperal Diabetes. Transactions of the Obstetrical Society of London, 1882, p. 271. Desprès [Hæmorrhoids]: Bulletin et Mémoire de la Société de Chirurgie, Paris, 1878, p. 480. Eulenstein : Die Ohrenkrankungen der Diabrtiker, Dentsches Archiv für Klinische Medicine, 1899, vol.1xvi., p. 270 (be gives a long bibliography). Exner: Ueber die Bedeutung des Harnzuckers fiir dhe Diagnose der Gallensteinkrankheit, Dentsche Medicinische Wochenschrift, 1898, Band xxiv., S. 491. Ferraro: Action du Glucose Wochenschrift, 1898, Band xxiv., S. 491. Ferraro: Action du Glucose Terapeutica, 1889. Fischer : Ueber den Nutzen der Carbolsäurebehand-

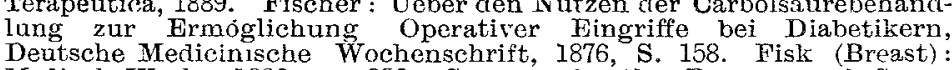
Medical Week, 1896, p. 256. Surgery in the Presence of Sugar
in the Urine, Annals of Surgery, April, 1900. Fort: Diabète in the Urine, Annals of Surgery, April, 1900. Fort: Diabétement de l'Uretère, Gazette des Hôpitaux de Paris, 1883. tome lvi.. p. 1178. Franeon: De l'Opération du Phimosis chez les Diabétiques, Lyon Mértical, tome liii. p. 242 . Friedrich Drei Falle ron Diab. Mastoiditis, Mnnchener Medicinische Wochenwith Temporary Glycosuria and Umbilical Hernia; Sub-peritoneal Hysterectomy and Radical Cure of Hernia; Recorery, British Gynæcological Journal, 1900, vol. xvi., p. 1. Godlee: On Amputation Chirurgical Society, vol. 1xxvi., p. 37. Grossman: Ueber Gangrain bei Diabetes Mellitus, Berlin, 1900. G. Gussenbauer: Ueber die Behandung ler Grangran bei Diabetes Mellitus, Wiener Klinische Wochenschrift, Mer Grangran bei Diabetes Mellitus, Wiener Klinische Wochenschrift,
1899 , S 45. Grube : Einige Beobachtungen uber die Bedeutung des Kalkes bei Diabetes Mellitus, Miinchener Medicinische Wochenschrift, 1895, Band xlii., S. 487. Hache : Fracture Comminutive des 4 Derniers Métatarses, Gangrene, Glycosurie, Résection de ces 4 Métatarses avec Metatarses, Gangrène, Glycosurie, Résection de ces 4 Métatarses avec
Conservation du Petit Orteil. Marche Facile, Revue de Chirurgie, 1890. tome $x$, p. 781 . Vaughan Harley : Diabetic Coma, its Etiology and
Suggestions as to its Treatment, Brit. Med. Jour., 1893, vol, ii., p. $6 \notin 6$. Suggestions as to its Treatment, Brit. Med. Jour., 1893, vol, ii., p. 666. Herman : De l'Influence de quelques Variations du Terrain Organique
sur l'Action des Microbes Pyogènes, Annales de l'Institut Pasteur, 1891, p. 253. Hoffa : Zur Vornahme grósserer Operationen an Diabetikern, Muinchener Medicinische Wochenschrift, 1888, Band xxxv., S. 888. Holsti : Fall af Diabetes Mellitus uppkomet efter en stót mot Magen,
Finska Läkare Sälisk. Handl., xxxvi., 871. Honl: Die BacterioFinska Lakkare Sälisk. Handl., xxxvi., 871. Honl : Die BacterioRundschau, Band xii., S. 245. Imlach: A Case of Diabetes Mellitus Cured by the Removal of the Uterine Appendages, Brit. Med. Jour., 1885, vol. ii., p. 61. Israel : Einige Beziehungen des Diabetes Mellitus zur Chirurgie, Berliner Klinische Wochenschrift, 1882, S. 705. Kast and Master : Ueber Stoff wechselstorungen nach länger dauernder Kleinwächter: Der Diabetes Mellitus rom Gybákologischen Standpunkt ausbetrachtet, Zeitschrift fïir Gebïrtshulfe und Gynäkologie, 1898, Band Xxxviii., S. 191; Tinige Worte über die Complieationen von Uterusmyom und Diabetes, ibid., 1900, Band xliii., p. 373; Noch einige Worte uber die Complicationen von Uterusmyom und Diabetes, ibia.,
1901 , Band xliv., p. 455 . König : Zur Revision der Lehre îber die Vor1901, Band xliv., p. 455. König: Zur Revision der Lehre iiber die Vor-
nahme grosseroperationen (Amputationen) bei Diab. Brand, Centralblatt nahme grosser Operationen (Amputationen) bei Diab. Brand, Centralblatt
fiir Chirurgie, 1887, Band xiv., S. 225. Kraske: Diabetes und Sepsis, ibid., fir Chirurgie, 1887, Band xiv., S. 225. Kraske: Diabetes und Sepsis, ibid." 1881, S. 545. Kreutzmann: Diabetes Mellitus and Carcinoma Uteri; 1898, vol. xxxviii., pp. 846-849. Landau : Carcinom Uteri und Coma 1898, vol. xxxviii,, pp. 846-849. Landau: Carcinom Uteri und Coma tionen bei gleichzeitig bestehender Zuckerhahnruhr, Berliner Klinische
Wochenschrift, 1888, Band xxv., S. 863 . Lannois: Les Affections de Wochenschrift, 1888, Band xxv., S. 863. Lannois: Les Affections de
l'Oreille chez les Diabétiques, Lyon Médical, 1900, tome xciii., p. 253; Mastoidite chez les Diabétiques, ibid., 1900, tome xcv., p. 498. Legendre:
Sur le Rôle de la Chirurgie dans le Diabète Sucré, Paris, 1895. Leidy: Sur le Rôle de la Chirurgie dans le Diabète Sucré, Paris, 1895. Leidy Three Cases of Glycosuria complicating Attacks of Appendicitis, Diabetes Melitus mit Erkrankungen der Weiblichen Sexualorgane, Berliner Klinische Wochenschrift, 1881, Band xviii., S. 601. Mannoury: Note pour servir à l'Histoire des Lésions Traumatiques chez les Minkowski : Ueber das Vorkommen von Oxybuttersaure im Harn bei Diabetes Mellitus, ein Beitrag zur Lehre von Coma Diabeticum, Archiv fir Experimentelle Pathologie und Pharmacologie, Leipsic, 1884, Diabetes, Aerztliches Intelligenzblatt, 1882, No. 41. Naunyn: Der Diabetes Mellitus, Wien, 1898. Neugebaner: Vor 4 . Nergehende GIycosurie bei Incarcerirter Hernie, Wiener Klinische Wochenschrift. 1896,
S. 825. Nicolas : Influence de la Glycosurie sur le Pouvoir Pyogène et 1a Virulence Générale du Staphylococcus Pyogenes Aureus. Archives do Médecine Experimentale et d Anatomie Pathologique, 1896, tome viii., p. 332. Noble: Three Operations upon Diabetic Patients, American
Journal of Obstetrics New York, 1899, vol. xxxix., pp. 105-108. Von Noorden: Pathologie des Stoffwechsels, Berlin, 1893. S. 416 . Nuzzi: La Glicosuria Efimera nell' Affezioni Chirurgichi, IIorgagni, Milano, 1889, vol. xxxi., pp. 593-611. Pàgenstecher : Die Chírurgischen Krankheiten und die Verletzungen des Pankreas (Kiorte, Deutsche Chirurgie, 45 d., p. 118, 1898). Railton and Southam: A Case of Strangulated Hernia producing Acetonæmia in a Diabetic Subject; Herniotomy under Cocaine; Coma; Death, Medical Chronicle, 1887, vol. vi., p. 16 Épulis chez un Diabétique, Courve de la Quantité de Glycose contenue dans l'Urine, avant et après Opération, Bulletin de l'Académie de Médecine, 1894, 3. série, tome xxxii., p. 15; De la Glycosurie Ephémère cans Aes Afections Chirurgicales, Revue de Chirurgie, 1866, pp. 638, 724 Reynier: Valeur du signe de Westphal (Perte du Réflexe Rotulien chez les Diabétiques, au point de vue chirurgical, Bulletin de la Société de Chirurgie, 1887, p. 444; Des Accidents Chirurgicaux Médecine et Chirurgie Pratílue de Paris, 1894, pp. 15-30. Richelot Ablation d'nn Épithéliome Intrabuccal chez un Diabétique, Cnion Médicale, 1883, tome xxxy.. p. 781. Rosenberger: Aerztliches

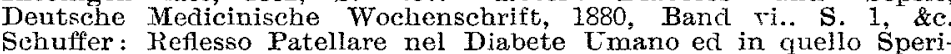
mentale. Bollettino di Società Lancisiana di Ospedali di Roma. 1897-1898. vol. xviii., pp. 13€-162. Schnaebele: Les Affections cle l'Oreille chez les Diabétiques. Lyon Médical, 1899. Sheppard: Two cases of Abscess in the Mastoid Region associated with Diabetes Mellitus, Medical News, 1896, vol. Ixviii, p. 494. Smith and Durham : Glyeosuria Spencer: Diabetes in Surgical Cases, Westminster Hospital lieports, 1888, vol. iv., p. 89. Upon Amputation in Diabetes Mellitus, Transactions of the Royal Medical and Chirurgical Society, 1E92, p. 395. Spitzer : U̇ber Traumatisches Coma Diabeticum, Deutsche Medicinische Wochensehrift, 1900, Band xxvi., S. 757. Stadelmann: Kilinische und Experimentelle Untersuchung liber Coma Diabeticum und seino Behandlung, Deutsche Medicinische Wochenschrft, 1889, Band xv, S. 938. Tuffier: Diabète et Néoplasmes, Arehives Générales, 1888. 7. série tome xxii., pp. 129, 314. Urqubart : Two Cases of Abscess in the Mastoid Region associated with Diabetes Mellitus, Medical News, 1896, vol. Chirurgie, 1878, p. 474; Divers Cas d'Affections Chirurgicales chez les Chirurgie, 1878, p. 474; Divers Cas d'Affections Chirurgicales chez les
Sujets Paludodiabétiques, Bulletin de l'Académie de Médecine, 1881, tome x., p. 1461 ; De la Consolidation des Fractures chez les Diabétiques, ibid., 1883, tome xii., p. 934; Paludisme et Diabète, ibid.. 1881, tome x-
Verneuil and Lucas Championnière: Rapport sur un Travail, Instit pour servir à l'Histoire des Lésions Traumatiques chez les Diabétiques, par Gabriel Mannoury, Bulletin et Mémoire de la Société de Chirurgie de Paris, 1879, N.S., tome v., pp. 755-757. Verneuil : Diabète et Traumatisme, ibid., 1884, p. 378. Wallace : Gangrene complicated by Glycosuria, Pia LAx Gangrene with Perforating Ulcer of the Foot Medical Press and Circular, 1885, N.S., vol. xl., p. 610. Waring : Acute Spreading Gangrene associated with Glycostria; Operation; Recovery, Brit. Med. Jour., 1897, vol. i., p. 849. Zeller (Gangrene) Cairo, Egypt.

\section{SOME NOTES FROM AN INQUTRY INTO THE ACTION OF DINITRO-BENZENE UPON THE URINE OF MAN,}

AND EXPERIMENTS PROVING THE MNOCUOUSNESS OF DINITRO-TOLUENE UPON ANIMALS.

By R. PROSSER WHITE, M.D. EdIN., M.R.C.S. ExG., HONORARY MFDICAI OFFICER TO THE ROYAL ALBERT EDWARD
INFIRMAAX, WIYAX;

JOHN HAY, M.D. VICT., M.R.C.S. ExG., \&C.,

MEDTCAL TUTOR AND RTGISTRAR AT THE ROTAL ETNFIRMARY, LITERPOOL, AND ASSISTANT PHYSTCTAN TO THE STANLEY HOSPITAI, LITERPOOL; AND

W. J. ORSMAN, F.C.S., F.I.C.,

LECTURER ON CIEMISTRY AT THE WIFAN TECHNICAL COLLEGE AXD ANALYST TO THE COUXTY BOROUGHS OF WIGAY AND SOUTHPORT.

Is this inquiry we find that a dose which is immediately fatal or fatal within 24 hours does not exhibit its presence in the urine of man or animals. On the other hand, animals fed upon continuous doses-that is, doses which cause serious and dangerous symptoms or death in a few days--show well-marked pathological features in their urine. These consist of tube casts, brown flakes, and hæmoglobinuria. This latter point has been well worked out by Strassmann and Stecker. In our experiments the dinitrobenzene was administered either hypodermically, or by inunction through the skin to cats. None of the urine of cats so killed showed any perceptible change of colour and in only one which had died from slow chronic poisoning did we find an indication of free dinitro-benzene.

In no fatal case of poisoning amongst the workmen hare we 
ever discovered any evidence of blool corpuscles or hamoglobin in the arine. In chronic and subacute cases the typical dark tawny colour of urine is always well marked, which is probably due to some pigmentary derivatives, not to free hæmoglobin. No doubt large and long-continued doses given by the mouth to men would produce, as in animals, hæmolysis, broken-up blood-clot in the intestines, and the exudation of blood into the tubules of the kidneys. But we find that neither in the inhalation of dinitro-benzene vapour, its absorption through the skin, nor when given hypodermically to man or animals, are the grosser lesions observed, even in fatal cases. 'This fact strengthens us in the belief that it is chiefly through absorption by the skin that cases of poisoning occur during the industrial manipulation of this substance.

We have ta'oulated below the results of the analysis of the urine of men who were constantly working with dinitrobenzene. Each case was of an exceedingly mild character. The frequent presence of urobilin has not been recorded previously and points to the powerful hæmolytic action of this poison even when absorbed in very minute doses. slight indication was found. This was in the case of a man who showed indications of poisoning and who had to leave off working.

A second question which has claimed our attention, and also a large proportion of the chemical trade interested in the practical manipulation of the toluene and benzene group of the nitrated aromatic series, is the comparative danger of these two groups. Commercially it is found that some of the toluene group can be substituted for the benzene in the manufacture of certain explosives. The employment of the benzene group is surrounded by a number of technical precautions. It is largely and widely becoming the custom where possible to substitute those of the series which are less harmful for those which experience has shown to be the more dangerous.

In an article in The LANCET of August 31st, 1901, p. 582, a statement was made by one of us that dinitro-toluene is consiclered highly deleterious and is dreaded by the workmen who are engaged in its production. This settled belief has been repeated to us and it appears to express the general consensus of the opinion of the employés and

A Table showisc the Resclts of the Axalisis of the Urine of Mex who were Constantly Workisc With Dinitro-Benzene.

\begin{tabular}{|c|c|c|c|c|c|c|c|c|c|c|}
\hline No. & $\begin{array}{c}\text { Specific } \\
\text { gravity } \\
\text { water }= \\
\text { 1000. }\end{array}$ & Appearance. & Colour. & $\mid$ & $\begin{array}{c}\text { Urea } \\
\text { per cent. }\end{array}$ & Albumin. & $\begin{array}{c}\text { Bile } \\
\text { pigments. }\end{array}$ & Sugar. & Lrobilin. & $\begin{array}{l}\text { Dinitro- } \\
\text { benzul. }\end{array}$ \\
\hline 1 & $10<9$ & Clarar. & Red-brown. & Acid. & $2 \cdot 6$ & Yil. & Nil. & Nil. & Nil. & Nil. \\
\hline 2 & 1030 & , , & Ycllow. &, & - & - & - & Precent. & - & $"$ \\
\hline 3 & $10 \_4$ & $\begin{array}{l}\text { Slight precipitate } \\
\text { mucus. }\end{array}$ & , & $"$ & - & Nil. & Nil. & Nil. & Nil. & $"$ \\
\hline 4 & 1021 & , $\quad$, & Red-brown. & ," & - & ," & ", & ", & ," & ,. \\
\hline 5 & 1025 & $\begin{array}{l}\text { Heary ren pre- } \\
\text { cipitate. }\end{array}$ & " " & , & - & , & ", & , & Present. & Trace. \\
\hline 6 & 1027 & Clear. &,$\quad$, & , & $3 \cdot 3$ & ,. & ", & , & sit. & Faint trace. \\
\hline 7 & 1026 & $\begin{array}{l}\text { Thick white pre- } \\
\text { cipitate. }\end{array}$ & Pale jellow. & , & $2 \cdot 9$ & , & ", & , &, & $", \quad "$ \\
\hline 8 & 1026 & Red deposit. & Red-brown. & ", & $3 \cdot 1$ & ," & ", & $"$ & Present. & Nil. \\
\hline 9 & 1022 &,$\quad \quad$, & & , & $3 \cdot 0$ & , & , & , & $"$ & $"$, \\
\hline 10 & 1022 & Clear. & Yellow: & , & $2 \cdot 8$ & , & , & , & Nil. & ," \\
\hline 11 & 1027 & Red deposit. & Reu-brown. & ", & $3 \cdot 1$ & Trace. & Trace. & ," & Present. & , \\
\hline 12 & 1025 &,$\quad$, & ", & ", & $\varepsilon \cdot 9$ & Nil. & Nil. & , & , & , \\
\hline 13 & 1024 & ", & ,. & ", & $2 \cdot 8$ & , & ,. & " & .. & " \\
\hline
\end{tabular}

It will be noticed in the above table that all the samples are acid, many being strongly so. Nearly all are dark-brown in colour and generally precipitate out a red deposit, principally urates. In most of these urobilin is present and can be easily recognised by the following test. 100 cubic centimetres of the urine are acidified with 10 drops of strong hydrochloric acid and are then shaken with 20 cubic centimetres of chloroform. The chloroform which falls to the bottom is separated by means of a separating funnel and filtered into a test-tube Four cubic centimetres of a solution of one gramme of crystallised acetate of zinc dissolved in a litre of 95 per cent. alcohol is then poured gently down the side of the test-tube and at the junction where the liquids meet a green fluorescent ring characteristic of urobilin will appear, and on shaking the solution will become fluorescent, being green by transmitted light and rosecoloured by reflected light. This pigment can also be detected by means of the spectroscope.

No experimental ev:dence has yet proved that reduction takes place in the body in case of the nitro compounds of benzene to aniline or phenylene-diamine. In several samples of urine tested both nitrates and nitrites were present, so that in the case of phenylene-diamine being present the pigment $B i$ marck brown would be formed and would give the urine a brown tint. The samples of urine were tested for free dinitro-benzene by the following method. The urine is treated with zinc and hydrochloric acid for some hours. Any dinitro-benzene that may be present is reduced by the nascent nydrugen into phenylene-diamine. The urine is then alkalined with caustic soda and well shaken up with ether. T'he ether is then separated, filtered, and evaporated. 'I'he resirlue is treated with diluted acetic acid and nitrite of soda, when a yellow or brown colouration shows the presence of dinitro-benzol in the original sample. In three cases a officials at certain works. Dr. T. M. Legge, H.M. medical inspector of factories, from his large experience of such industries, thought there might be some doubt on this point. We therefore deemed it advisable to experiment upon animals. with the following results. To two cats were administered a 1 per cent. solution of dinitro-toluene in cod-liver oil. The quantity given was two cubic centimetres in the morning and two cubic centimetres in the evening daily until each had partaken of 24 cubic centimetres. Neither cat exhibited any symptoms of poisoning. Two weeks later one of the above cats and a second fresh cat were each dosed with a 1 per cent. solution of dinitrotoluene in cod-liver oil, four cubic centimetres in the morning and four cubic centimetres in the evening until each cat had received 24 cubic centimetres, with no result except a very slight change in the colour of the mucous membrane.

These experiments prove that to cats dinitro-toluene is rather a harmless drug and if we compare it with the results published in the article in THE LANCET already alluded to where similar doses of dinitro-benzene were administered to cats the contrast is most marked. It must be remembered that these exprriments deal with animals, but our experience with allied yroups of the aromatic series show a close similarity of action when they are exhibited to animals and men and further industrial experience strengthens our belief that mono- di- and tri-nitro-toluene can be safely manipulated with ordinary precautions.

Notification of Chrcken-Pox - At the meeting of the Falmouth Corporation held on May 8th it was decided, on the recommendation of the Sanitary Committee, to make chicken-pox a notifiable disease for six months. 